\title{
Importance of origin in rice purchasing decisions in Talca and Temuco, Chile
}

\author{
Berta Schnettler ${ }^{1}$, Danilo Ruiz¹, Oriana Sepúlveda ${ }^{1}$, José Sepúlveda², and \\ Marianela Denegri ${ }^{2}$ \\ ${ }^{1}$ Departamento de Producción Agropecuaria, and ${ }^{2}$ Departamento de Psicología \\ Universidad de La Frontera. Casilla 54-D, Temuco, Chile.
}

\begin{abstract}
B. Schnettler, D. Ruiz, O. Sepúlveda, J. Sepúlveda, and M. Denegri. 2009. Importance of origin in rice purchasing decisions in Talca and Temuco, Chile. Cien. Inv. Agr. 36(2):239248. Considering the increase in imports of forestry, farming and livestock products to Chile, the existence of different consumer segments was evaluated according to the relative importance of origin in decisions to purchase rice in Talca and Temuco in central-southern Chile. With this purpose, a direct survey was administered to 800 consumers, 400 in Talca (Maule Region) and 400 in Temuco (Araucanía Region). Using a conjoint analysis and hierarchical clustering, five market segments were distinguished. The largest group (35.4\%) gave great importance to the origin of the rice. The second largest group $(25.1 \%)$ gave greater relevance to the packaging. For the third and fourth largest groups (15.4 and 12.5\%, respectively), the cost of the product was the most important attribute. The smallest group (11.6\%) gave slightly higher importance to the origin of the rice than the other attributes. Only this final group preferred imported rice. Therefore, the results of this investigation make it possible to conclude that the origin of the rice is an important attribute for $47 \%$ of the consumers in Talca and Temuco, Chile. The other groups based their purchase decisions on the price or the product packaging. The highest proportion of consumers $(88.4 \%)$ preferred domestic rice.
\end{abstract}

Key words: Importation, market segmentation, origin, Oryza sativa, rice.

\section{Introduction}

In an environment characterized by market globalization, the attribute of "country of origin" may be used to add value to the product and differentiate it from competitors (Baker and Ballington, 2002). Consumers differentiate among products from different countries of origin (Verlegh et al., 2005; Orth and Firbasová, 2003; Agrawald and Kamakura, 1999; Verlegh and

Received 13 August 2008. Accepted 31 December 2008.

Corresponding author: bschnett@ufro.cl
Steenkamp, 1999). This phenomenon is known as the "effect of country of origin" (Verlegh et al., 2005; Agrawald and Kamakura, 1999) and implies that consumers use a product's origin as an attribute related to its quality, alone or in combination with other attributes (Balestrini and Gamble, 2006; De Cicco et al., 2001; Gürhan-Canli and Maheswaran, 2000).

The country of origin has a great impact on the evaluation of a product when consumers have little time for purchase decisions, as occurs with food (Grunert, 2005; Ahmed et al., 2004; Gürhan-Canli and Maheswaran, 2000; Lantz and Loeb, 1996). Several studies account for 
the importance of food origin in choosing food, and a normal preference for domestic products or those produced in the country of birth of the consumer are associated with a high degree of ethnocentrism (Schnettler et al., 2008, 2004; Chambers et al., 2007; Balestrini and Gamble, 2006; Verlegh et al., 2005; Alfnes, 2004; Orth and Firbasová, 2003; Baker and Ballington, 2002; Kaynak et al., 2000; Lantz and Loeb, 1996).

On the contrary, other investigations have determined that food origin does not have a significant effect on the perception of product quality (Verbeke and Ward, 2006; Bernués et al., 2003; Acebrón and Dopico, 2000) or the preferences of the consumer (Bonnet and Simioni, 2001; van der Lans et al., 2001).

The country of origin effect is only detected in some products and with uneven intensity. Therefore, a generalization to any product or country is not possible (van Ittersum et al., 2003). There is also evidence of rejection of domestic products and preference for imported products when the local food is of poor quality (Knight et al., 2008; Tomlins et al., 2005). Likewise, attitudes toward imported food are not uniform for all consumers. In this regard, there is evidence that the perceptions of foods from different origins depend on age, gender, educational level and the country of residence of the consumer (Chambers et al., 2007; Ozretic-Dosen et al., 2007; Verbeke and Ward, 2006; Tomlins et al., 2005; Alfnes, 2004, Rojsek; 2001; Juric and Worley, 1998; Witkowski, 1996). Previous studies have differentiated segments of European consumers in relation to their acceptance of foods of diverse origin, with groups preferring imported products, domestic products, or having no preference for a specific origin (Oliver et al., 2006). In Ghana, Tomlins et al. (2005) differentiated four segments of consumers according to their acceptance of different types of domestic and imported rice.

Since 1992, Chile has subscribed to several international commercial agreements allowing increasing exports and imports of silvoagropecuarian products. Regarding only imports of silvoagropecuarian products, imports increased $162 \%$ between 2000 and 2007, from US $\$ 1.128$ million to US\$2.957 million (ODEPA, 2008), allowing Chilean consumers to purchase a wider range of imported foods.

Rice (semi-bleached or bleached) is among the main foods imported, with an increase of $261 \%$ in imports recorded between 2000 and 2007 (56,145 to 202,784 tons). In the 2006-2007 season, imports exceeded the national rice production by $44.8 \%$ (ODEPA, 2008). Based on this background, the objective of this study was to differentiate consumer segments in the centralsouthern part of Chile according to the importance they place on the country of origin of rice with respect to other extrinsic attributes of the product (e.g., price, packaging).

\section{Materials and methods}

\section{Survey}

A personal survey was administered to a sample of 800 rice consumers older than 18 years, 400 from Talca (Region of Maule, $35^{\circ} 25^{\prime}$ S, $71^{\circ} 40^{\prime}$ W) and 400 from Temuco (Region of Araucanía, $38^{\circ} 45^{\prime} \mathrm{S}, 73^{\circ} 03^{\prime} \mathrm{W}$ ), Chile. The number of surveyed consumers was obtained by a simple random sampling formula for non-finite populations ( $\mathrm{N}>100,000$; Talca: 201,797 inhabitants and Temuco: 245,347 inhabitants at 2002 Census), considering a $95 \%$ confidence interval and $5 \%$ of error of estimation with $p$ and $q$ of 0.5 (Fernández, 2002).

A questionnaire was completed with closedended questions on consumption of imported foods and reasons to purchase them instead of Chilean foods or not. Classification questions included: gender, age, size of family group, zone of residence, occupation, education level of the head of household, and ownership of ten home goods. These last two variables were included to determine respondents' socioeconomic group, classified as $\mathrm{ABC} 1$ (high and medium high), C2 (medium-medium), C3 (medium-low), D (low) and E (very low) (Anonymous, 2004). The survey was carried out in two supermarkets in Temuco and Talca between April and June of 2007 , after validating the questionnaire by 
a preliminary test of $10 \%$ of the sample to be tested.

\section{Statistical analysis}

A conjoint analysis was used to determine the importance of origin in rice purchasing decisions, which permitted estimation of the relative importance and partial values of utility or preference for the following attributes and levels: 1 . Origin (domestic and imported), 2. Packaging (bag and box), 3. Price. Because consumers' rejection of imported meat was not compensated for by a price discount of 15\% (Schnettler et al., 2004), higher discounts were used, which corresponded to $25 \%\left(0.78 \mathrm{US} \$ \cdot \mathrm{kg}^{-1}\right)$ and $50 \%(0.52$ US\$ $\left.\mathrm{kg}^{-1}\right)$ off the average price of rice sold to consumers between January 2005 and March $2006\left(1.05\right.$ US\$ $\left.\cdot \mathrm{kg}^{-1}\right)$, expressed in the currency of April 2006. The national currency values (Chilean pesos) were converted to dollars using the average 2007 value (\$522.46/US\$). Twelve combinations were obtained from these attributes and levels $(2 \times 2 \times 3$, origin $\times$ container $\mathrm{x}$ price).

The function of preference corresponded to the Ideal Point Model (Hair et al., 1999). The data were obtained by the total profile procedure; therefore, 12 cards were elaborated with specifications for each attribute. Each survey respondent ordered the cards from the most preferred to the least preferred on a scale from 1 to 12 , where $1=$ most preferred and $12=$ least preferred. A linear relation was established for the price attribute, because the preference is lower with a higher price. The remaining attributes were considered as discrete variables. A Pearson correlation was used to determine the goodness of fit of the model, and the Kendall Tau correlation was used to determine if the arrangement of stimuli estimated according to the arrangement function corresponded with the real arrangements of the survey respondents (Hair et al., 1999).

In order to segment consumers according to the importance they place on and preferences toward origin, packaging and price of rice, hierarchical cluster analysis was used, with the method of
Ward as a way of chaining and with the square Euclidean distance as a measure of likelihood among objects (Hair et al., 1999). The number of clusters was obtained through an observation of the dendrogram and was confirmed by determining the percentage of change of the recomposed conglomeration coefficients. To describe the segments, a Pearson's chi-squared test $\left(\chi^{2}\right)$ was applied to the discrete variables, and analysis of variance was performed for the values of importance of the attributes and preferences of the attribute levels at $p \leq 0.05$. The averages of variables with significant differences $(\mathrm{p} \leq 0.05)$ were separated according to the Tukey test of multiple comparisons (Lea et al., 1997). The statistical program SPSS 14.0 was used for data analysis (SPSS, Inc., Chicago, EUA).

\section{Results}

The survey sample had equal proportions of consumers from Talca and Temuco, with $42.4 \%$ men and $57.6 \%$ women; $33.8 \%$ were aged less than 35 years, $46.8 \%$ were between 35 and 49 years old, $14.8 \%$ were between 50 and 64 years old, and $4.8 \%$ were over 65 years old. Fifteen percent of respondents' families had one or two members; $56.5 \%$ had three or four members, and $28.5 \%$ had five or more members, with $87.6 \%$ of the sample residing in an urban area and $12.4 \%$ in rural zones. Twenty five percent were independent workers; $9.9 \%$ businessmen; $34.9 \%$ private employees; $12.9 \%$ public employees; $9.8 \%$ retired; $2.0 \%$ unemployed and 5.6\% in other labor situations. Breaking down the sample by socioeconomic status, $19.9 \%$ of the respondents were in socioeconomic group $\mathrm{ABCl}$ (high and medium-high); $28.1 \%$ in $\mathrm{C} 2$ (medium-medium); $29.8 \%$ in C3 (medium-low); $21.4 \%$ in D (low), and $0.9 \%$ in $\mathrm{E}$ (very low).

Most of the survey respondents indicated the consumption of imported foods $(93.7 \%$; $\mathrm{n}=750$ ), which were preferred for being cheaper $(50.7 \%)$, presenting a good price/quality relation (35.7\%), being of better quality $(7.0 \%)$, because good Chilean substitutes do not exist (6.3\%), and for other reasons $(0.4 \%)$. Among the consumers who do not purchase imported foods $(6.3 \%$; $\mathrm{n}=50$ ), the reasons for this behavior were the 
privilege of Chilean products (52\%), lower quality of imported foods (44.0\%) and the increased expense of imported versus Chilean foods $(4.0 \%)$.

According to the conjoint analysis, the country of origin was slightly more important (34.16\%) than the price $(33.23 \%)$ and the packaging $(32.60 \%)$ in the purchase decision. The consumers preferred the Chilean rice in a bag and rejected the discounted prices (figures of negative preference). The Pearson and Kendall Tau coefficients of correlation ( 0.928 and 0.958 , respectively) were significant $(\mathrm{p}=0.001)$ and close to 1 . Through conglomerate analysis it was possible to differentiate significantly ( $\mathrm{p} \leq$ 0.05 ) five groups of consumers with regard to the importance placed on the origin, packaging and price of rice (Table 1). rejection of the foreign product, significantly stronger than the rest of the groups' (Table 1). This segment assigned similar importance to the packaging (21.1\%) and price (20.7\%). According to these results, Group 5 corresponded to consumers sensible to origin who prefer domestic rice (Table 1). In relation to the total sample, Group 5 contained a superior proportion of persons working independently $(29.5 \%)$ who do not purchase imported foods (16.7\%) (Table 2).

The second group (Group 3, $\mathrm{n}=201$ ) consisted of $25.1 \%$ of the survey respondents who assigned greater importance to the rice container $(57.5 \%)$, significantly $(\mathrm{p} \leq 0.05)$ higher than the rest of the groups. The importance of origin was low $(20.1 \%)$ and statistically similar to Groups 1 and 2 and lower than Groups 4 and $5(\mathrm{p} \leq 0.05)$. Preference for Chilean rice (0.896) was statisti-

Table 1. Importance of origin, packaging and price in the decision-making process when purchasing rice and utilities of the levels of each attribute from groups obtained by cluster analysis, Regions of Maule and Araucanía, Chile. June, 2007.

\begin{tabular}{lcccccccc}
\hline & $\begin{array}{l}\text { Total } \\
\text { sample }\end{array}$ & $\begin{array}{l}\text { Group 1 } \\
(\mathrm{n}=100)\end{array}$ & $\begin{array}{l}\text { Group 2 } \\
(\mathrm{n}=123)\end{array}$ & $\begin{array}{l}\text { Group 3 } \\
(\mathrm{n}=201)\end{array}$ & $\begin{array}{l}\text { Group 4 } \\
(\mathrm{n}=93)\end{array}$ & $\begin{array}{l}\text { Group 5 } \\
(\mathrm{n}=283)\end{array}$ & $\mathrm{F}$ & $\mathrm{p}$ \\
\hline $\begin{array}{l}\text { Importance of the attributes } \\
\text { Origin, \% }\end{array}$ & 34.3 & $13.8 \mathrm{c}^{2}$ & $14.1 \mathrm{c}$ & $20.1 \mathrm{c}$ & $40.8 \mathrm{~b}$ & $58.2 \mathrm{a}$ & 602.959 & $\leq 0.001$ \\
Packaging, \% & 32.4 & $22.2 \mathrm{c}$ & $24.6 \mathrm{c}$ & $57.5 \mathrm{a}$ & $33.1 \mathrm{~b}$ & $21.1 \mathrm{c}$ & 320.069 & $\leq 0.001$ \\
Price, \% & 33.3 & $64.0 \mathrm{a}$ & $61.3 \mathrm{a}$ & $22.4 \mathrm{bc}$ & $25.1 \mathrm{~b}$ & $20.7 \mathrm{c}$ & 601.795 & $\leq 0.001$ \\
Preference for each level of the attributes ${ }^{1}$ & & & & & & & \\
Domestic & 1.243 & $0.517 \mathrm{c}$ & $0.467 \mathrm{c}$ & $0.896 \mathrm{~b}$ & $-1.343 \mathrm{~d}$ & $2.944 \mathrm{a}$ & 687.710 & $\leq 0.001$ \\
Imported & -1.243 & $-0.517 \mathrm{~b}$ & $-0.467 \mathrm{~b}$ & $-0.896 \mathrm{c}$ & $1.343 \mathrm{a}$ & $-2.944 \mathrm{~d}$ & 687.710 & $\leq 0.001$ \\
Bag & 1.028 & $0.597 \mathrm{bc}$ & $0.445 \mathrm{c}$ & $2.988 \mathrm{a}$ & $-1.255 \mathrm{~d}$ & $0.789 \mathrm{~b}$ & 367.686 & $\leq 0.001$ \\
Box & -1.028 & $-0.597 \mathrm{bc}$ & $-0.445 \mathrm{~b}$ & $-2.988 \mathrm{~d}$ & $1.255 \mathrm{a}$ & $-0.789 \mathrm{c}$ & 367.664 & $\leq 0.001$ \\
1.05 US\$ $\cdot \mathrm{kg}^{-1}$ & -0.261 & $3.233 \mathrm{a}$ & $-2.763 \mathrm{~d}$ & $-0.025 \mathrm{~b}$ & $-0.194 \mathrm{~b}$ & $-0.599 \mathrm{c}$ & 414.932 & $\leq 0.001$ \\
0.78 US\$ $\cdot \mathrm{kg}^{-1}$ & -0.521 & $6.467 \mathrm{a}$ & $-5.526 \mathrm{~d}$ & $-0.051 \mathrm{~b}$ & $-0.389 \mathrm{~b}$ & $-1.199 \mathrm{c}$ & 414.932 & $\leq 0.001$ \\
0.52 US\$ $\cdot \mathrm{kg}^{-1}$ & -0.782 & $9.701 \mathrm{a}$ & $-8.289 \mathrm{~b}$ & $-0.076 \mathrm{~b}$ & $-0.584 \mathrm{~b}$ & $-1.798 \mathrm{c}$ & 414.934 & $\leq 0.001$ \\
\hline
\end{tabular}

${ }^{1}$ Utility numbers in the different levels from an attribute with a negative sign indicate utility loss for the consumer.

${ }^{2}$ Means followed by the same letters in each row are not statistically different according to Tukey's multiple comparison test $(\mathrm{p} \leq 0.05)$.

Group 5 was the majority $(\mathrm{n}=283$ ): $35.4 \%$ of the survey respondents gave great importance to the origin of rice $(58.2 \%)$, significantly $(\mathrm{p} \leq 0.05)$ higher than the rest of the groups. In this group, the positive preference (2.944) toward Chilean rice indicates a preference for this origin that was significantly ( $p 0.05$ ) higher than the other groups'. The value of negative preference regarding imported rice (-2.944) indicates a strong cally lower than Group 5 but higher than Groups 1,2 and 4. Group 3 corresponded to consumers preferring Chilean rice and sensible to its packaging (Table 1). Group 3 had a high proportion of consumers from Talca (65.2\%) and fewer consumers in the $\mathrm{ABC} 1$ socioeconomic class $(12.9 \%)$, and its members preferred imported foods due to the unavailability of good Chilean substitutes (3.0\%) (Table 2). 
Table 2. Demographic features and attitudes toward imported foods with statistical differences among groups obtained by cluster analysis, Regions of Maule and Araucanía, Chile. June, 2007.

\begin{tabular}{|c|c|c|c|c|c|}
\hline & $\begin{array}{l}\text { Group 1 } \\
(\mathrm{n}=100)\end{array}$ & $\begin{array}{l}\text { Group 2 } \\
(\mathrm{n}=123)\end{array}$ & $\begin{array}{l}\text { Group 3 } \\
(\mathrm{n}=201)\end{array}$ & $\begin{array}{l}\text { Group } 4 \\
(\mathrm{n}=93)\end{array}$ & $\begin{array}{l}\text { Group 5 } \\
(\mathrm{n}=283)\end{array}$ \\
\hline City & $\mathrm{p}=0.001$ & & & & \\
\hline Temuco & 57.0 & 61.8 & 34.8 & 68.8 & 46.6 \\
\hline Talca & 43.0 & 38.2 & 65.2 & 31.2 & 53.4 \\
\hline Age & $\mathrm{p}=0.034$ & & & & \\
\hline$<35$ years & 33.0 & 33.3 & 35.3 & 31.2 & 33.8 \\
\hline $35-49$ years & 51.0 & 49.6 & 49.3 & 33.3 & 46.6 \\
\hline 50-64 years & 13.0 & 10.6 & 11.4 & 26.9 & 15.7 \\
\hline 65 years and over & 3.0 & 6.5 & 4.0 & 8.6 & 3.9 \\
\hline Family size & $\mathrm{p}=0.008$ & & & & \\
\hline $1-2$ family members & 8.0 & 18.7 & 16.9 & 15.1 & 14.6 \\
\hline 3-4 family members & 52.0 & 55.3 & 59.2 & 45.2 & 60.9 \\
\hline 5 or more & 40.0 & 26.0 & 23.9 & 39.8 & 24.6 \\
\hline Occupation & $\mathrm{p}=0.014$ & & & & \\
\hline Independent workers & 23.0 & 20.3 & 25.9 & 17.2 & 29.5 \\
\hline Businessmen & 16.0 & 7.3 & 7.0 & 10.8 & 10.7 \\
\hline Private Sector Employee & 32.0 & 39.0 & 37.8 & 30.1 & 33.8 \\
\hline Public Employee & 20.0 & 8.9 & 10.4 & 20.4 & 11.0 \\
\hline Retired & 7.0 & 13.0 & 10.0 & 11.8 & 8.5 \\
\hline Unemployed & 1.0 & 4.9 & 1.5 & 3.2 & 1.1 \\
\hline Other & 1.0 & 6.5 & 7.5 & 6.5 & 5.3 \\
\hline Socioeconomic group & $\mathrm{p}=0.001$ & & & & \\
\hline $\mathrm{ABC} 1$ & 36.0 & 13.8 & 12.9 & 24.7 & 19.9 \\
\hline $\mathrm{C} 2$ & 22.0 & 29.3 & 32.3 & 34.4 & 24.6 \\
\hline $\mathrm{C} 3$ & 26.0 & 34.1 & 29.9 & 15.1 & 34.2 \\
\hline $\mathrm{D}$ & 16.0 & 20.3 & 24.4 & 23.7 & 21.0 \\
\hline E & 0 & 2.4 & 0.5 & 2.2 & 0.4 \\
\hline Buy imported food & $\mathrm{p}=0.001$ & & & & \\
\hline Yes & 99.0 & 99.2 & 100 & 100 & 82.9 \\
\hline No & 1.0 & 0.8 & 0 & 0 & 16.7 \\
\hline Don’t know & 0 & 0 & 0 & 0 & 0.4 \\
\hline Reasons to prefer imported food & $\mathrm{p}=0.001$ & & & & \\
\hline Greater quality & 5.1 & 4.1 & 8.5 & 16.1 & 4.3 \\
\hline Cheaper & 48.5 & 43.4 & 55.7 & 43.0 & 54.1 \\
\hline Price/quality ratio & 37.4 & 45.9 & 32.8 & 24.7 & 36.5 \\
\hline Lack of national substitute & 9.1 & 4.9 & 3.0 & 16.1 & 4.7 \\
\hline Others & 0 & 1.6 & 0 & 0 & 0.4 \\
\hline
\end{tabular}

$\mathrm{p}$ value is the asymptotic significance (bilateral) obtained by Pearson $\chi^{2}$ test.

The third group (Group 2) $(\mathrm{n}=123)$ was statistically similar to Group 1 and higher than Groups $3,4$ and 5 ( $\mathrm{p} \leq 0.05)$; it consisted of $15.4 \%$ of the sample of survey respondents who gave great importance to rice price $(61.3 \%)$. The importance of origin was low (14.1\%), statistically similar to Groups 1 and 3 and lower than Groups 4 and 5 (p $\leq 0.05)$. Preference for Chilean rice $(0.467)$ was statistically similar to Group 1 and lower than Groups 3, 4 and 5. According to these results, Group 2 included consumers preferring Chilean rice and sensible to price (Table 1). Group 2 presented a higher proportion of consumers from Temuco (61.8\%), unemployed consumers (4.9\%), and people preferring imported foods due to a good price/quality relation (45.9\%) (Table 2 ).

The fourth group (Group 1) $(\mathrm{n}=100)$, consisting of $12.5 \%$ of the survey respondents, also assigned great importance to rice price $(64.0 \%)$, statistically similar to Group 2 and higher than Groups 3, 4 and 5 ( $\mathrm{p} \leq 0.05)$. Similarly, the im- 
portance of origin was low (13.8\%), statistically similar to Groups 2 and 3 and lower than Groups 4 and 5 ( $\mathrm{p} \leq 0.05)$. Preference for domestic rice (0.517) was statistically similar to Group 2 and lower than Groups 3, 4 and 5. Group 1 was the only group presenting positive preference values regarding price levels, significantly higher than the rest of the groups ( $\mathrm{p} \leq 0.05)$. The preference was increased when paying lower prices; therefore, Group 1 represents consumers who value discounts and prefer Chilean rice (Table 1). Group 1 presented higher proportions of numerous families $(40.0 \%)$, businessmen $(16.0 \%)$, public employees (20\%), and people belonging to socioeconomic group $\mathrm{ABC} 1$ (36.0\%) (Table 2).

Group 4 was small $(n=93)$ and significantly inferior to Group 5 and superior to Groups 1, 2 and 3 ( $\mathrm{p} \leq 0.05$ ); it consisted of $11.6 \%$ of the survey respondents who gave a slightly higher importance to rice origin $(40.8 \%)$. Group 4 was the only group presenting a positive preference for imported rice (1.343), significantly higher than the rest of the groups ( $\mathrm{p} \leq 0.05)$, and negative preference of or rejection for Chilean rice (-1.343), significantly lower than the remaining groups $(\mathrm{p} \leq 0.05)$. This group may be called consumers sensible to origin who prefer imported rice (Table 1). Group 4 presented a higher proportion of consumers from Temuco $(68,8 \%)$, between 50 and 64 years old $(26.9 \%)$, public employees (20.4\%), and persons who acknowledge higher quality in imported rice than in Chilean rice (16.1\%) and the unavailability of good Chilean substitutes (16.1\%). In addition, it presents a lower percentage of persons of $\mathrm{C} 3$ socioeconomic status (Table 2).

Similar to the total sample, consumers of Groups 1, 2, 3 and 5 preferred bags (positive figures of preference) and rejected boxes as packaging. Group $4(11.6 \%)$ showed the opposite preference.

\section{Discussion}

According to the results, it is possible to divide the population of Talca and Temuco into five groups according to the importance assigned to the origin when purchasing rice. The utility estimates indicated the degree of preference or rejection for each level of each attribute (Hair et al., 1999). Thus, it was determined that the highest proportion of consumers prefer Chilean rice $(88.9 \%)$, which confirms the results previously obtained with respect to the preference for domestic products (Schnettler et al., 2008, 2004; Chambers et al., 2007; Alfnes, 2004; Baker and Ballington, 2002; Kaynak et al., 2000). If it is considered that consumers use origin as an attribute related to product quality (Balestrini y Gamble, 2006; De Cicco et al., 2001; GürhanCanli and Maheswaran, 2000), it is possible to suggest that the survey respondents perceive better quality in Chilean rice. In fact, the attitude toward domestic foods is not unconditional; there is a preference for imported foods if they are of better quality than their domestic equivalents (Knight et al., 2008; Tomlins et al., 2005).

In this investigation, the Pearson and Kendall Tau correlation coefficients showed a strong goodness of fit of the conjoint model, and the arrangement obtained corresponded to the global arrangement of the survey respondents (Hair et al., 1999). In the total sample, the consumers assigned similar importance to the attributes of origin, packaging and price, indicating that none of these attributes drives consumer preferences (Baker and Burnham, 2002). Nevertheless, the segmentation criteria based on the use of multivariate techniques, conjoint analysis and hierarchical cluster analysis permitted the analysis of different behaviors in the five segments of consumers obtained according to their purchasing behavior in Talca and Temuco, Chile (Andrews and Currim, 2003).

Therefore, two groups of consumers were obtained for whom the origin of the rice was the dominant factor in the purchase decision (Groups 4 and 5; 47\% of the sample) and three groups for whom this attribute had limited importance (Groups 1, 2 and 3; 53\%). Therefore, in addition to the fact that the effect of the country of origin cannot be extended to any product or country (van Ittersum et al., 2003), this may also be true within certain populations. Therefore, the result of Groups 4 and 5 is in accordance with previous studies on yogurt (Orth and Firbasová, 2003; Lantz and Loeb, 1996), wine 
(Balestrini and Gamble, 2006), and beef (Schnettler et al., 2008, 2004; Alfnes, 2004). The results from Groups 1, 2 and 3 are in accordance with other investigations (Verbeke and Ward, 2006; Bernués et al., 2003; Acebrón and Dopico, 2000) that indicate a nonsignificant effect of the country of origin in consumer purchasing decisions. In this investigation, this could be because the countries of origin of imported rice were not specified in the cards presented to the respondents. Grunert (2005) indicates that consumer's decision is not affected by the country of origin if he lacks knowledge of the zone of origin of the product. Nevertheless, if this result is compared with the result obtained by Schnettler et al. (2004) for beef, similarly using only domestic and imported origins, it is apparent that the importance of origin in the purchasing decision differs for different types of foods (van Ittersum et al., 2003).

The presence of different segments of consumers in relation to the importance of origin is coherent with results reported in Europe and Africa for beef and rice (Oliver et al., 2006; Tomlins et al. 2005). In this investigation, it was possible to confirm that the perceptions of foods of different origins are affected by age (Chambers et al., 2007; Verbeke and Ward, 2006; Alfnes, 2004, Juric and Worley, 1998; Witkowski, 1996) and the place of the consumer's residence $(\mathrm{Oz}-$ retic-Dosen et al., 2007; Tomlins et al., 2005; Rojsek; 2001). However, it did not confirm the relation between the acceptance of national and imported foods and gender (Chambers et al., 2007; Tomlins et al., 2005; Alfnes, 2004; Juric and Worsley, 1998) and educational level (Verbeke and Ward, 2006; Juric y Worley, 1998; Witkowski, 1996).

However, the differences detected among the groups according to age are only in partial accordance with results from previous studies (Verbeke and Ward, 2006; Juric and Worsley, 1998) pointing out that the importance of origin is higher for older consumers. A larger presence of older consumers was detected only in Group 4 (26.9\% of persons between 50 and 64 years old), which assigned $40.8 \%$ importance to rice origin, not in Group 5, which gave the highest importance to the origin attribute. Similarly, the rejection of Chilean rice and preference for imported rice obtained in Group 4 opposes the higher preference for domestic products detected in older persons in Norway (Alfnes, 2004) and the United Kingdom (Chambers et al., 2007). However, the preference for imported rice in this group is coherent with the greater proportion of persons indicating a preference for imported foods because of their higher quality (16.1\%) and the unavailability of good Chilean substitutes (16.1\%). The segment showing a higher preference for domestic rice and higher rejection for imported rice was only different from the rest of the segments because of the greater presence of persons working independently $(29.5 \%)$ and persons who do not purchase imported foods (16.7\%). This fact, which could be attributed to the existence of ethnocentric behavior as in (Chambers et al., 2007; Kaynak et al., 2000; Witkowski, 1998), should be investigated further.

Although differences were detected among groups according to the city of residence of the consumer, there were not clear tendencies based on this aspect. Considering that rice production in Chile is centered in the Region of Maule (Talca) and an increase has occurred in rice imports, a regional ethnocentric effect could have been expected; that is, an evident rejection of imported rice by consumers from Talca. Ethnocentrism makes the consumer think about how purchasing products damages the national or regional economy and causes unemployment (Witkowski, 1998). The group attributing greater importance to origin and presenting a higher preference for domestic rice (Group 5) did not differ statistically from the total sample regarding the shares of consumers from Talca and Temuco. On the contrary, the only group having a larger proportion of consumers from Talca (Group 3; 65.2\%) gave more relevance to the packaging. Nevertheless, it is interesting that the group preferring imported rice contains more consumers from Temuco, even though it is the smallest segment.

The great importance assigned to price by the consumers from Groups 1 and 2 is coherent with the results obtained in a study on chocolate preferences in Europe (Ozretic-Dozen et al., 2007). In the case of Group 2, there is congruence with the greater presence of consumers preferring imported foods due to the good price/ 
quality relation $(45.9 \%)$. In this regard, the rejection of the discount prices in the total sample and in most of the segments identified (Groups 2, 3,4 and 5) shows an association between price and quality (Stiving, 2000). Price is an important quality indicator when making the wrong decision involves a certain degree of risk. Therefore, in some cases the consumers may reject cheaper products to avoid the risk of dissatisfaction with the purchase (Kotler, 2002). Conversely, the only group showing a preference for discounted prices contained a greater proportion of persons of high socioeconomic stratus (Group 1; 36.0\% ABC1) and entrepreneurs (16.0\%). However, this behavior may be explained by a higher proportion of these consumers belonging to families with five or more members $(40.0 \%)$. Consumers purchasing in large amounts are more likely to prefer more economic alternatives, which may provide significant savings (Baltas y Doyle, 1998).
Therefore, although segments of consumers assigning different relevance to the origin of rice purchased were obtained, there is an important proportion of consumers (47\%) whose purchase decisions are driven by this attribute. Regardless of the importance assigned to origin in rice purchasing, the majority prefer the Chilean product, indicating an opportunity for the domestic rice industry. The attribute of country of origin may be used to promote domestic products in the local market, emphasized in this case by growing competition from foreign products.

\section{Acknowledgments}

The authors are very grateful for the financial support received from FONDECYT, project 1080146 and DIUFRO, project 120601.

\title{
Resumen
}

\begin{abstract}
B. Schnettler, D. Ruiz, O. Sepúlveda, J. Sepúlveda y M. Denegri. 2009. Importancia del origen en la decisión de compra de arroz en Talca y Temuco, Chile. Cien. Inv. Agr. 36(2):239-248. Considerando el aumento de las importaciones de productos silvoagropecuarios en Chile, se evaluó la existencia de diferentes segmentos de consumidores según la importancia relativa del origen en la compra de arroz en la zona centro-sur de Chile. Para esto se realizaron encuestas directas a 800 consumidores, 400 de la ciudad de Talca (Región del Maule) y 400 de Temuco (Región de La Araucanía). Mediante análisis conjunto y análisis de conglomerados jerárquicos se distinguieron cinco segmentos de mercado. El más numeroso $(35,4 \%)$ concedió gran importancia al origen del arroz, el segundo grupo en importancia $(25,1 \%)$ otorgó mayor relevancia al envase, el tercer y cuarto grupo en importancia ( 15,4 y $12,5 \%)$ dieron alta relevancia al precio del producto, mientras el grupo minoritario (11,6\%) dio leve mayor importancia al origen del arroz. Sólo este último grupo prefirió arroz importado. Por lo tanto, los resultados de esta investigación permiten concluir que el origen del arroz es un atributo de importancia para $47 \%$ de los consumidores de Talca y Temuco, el resto basó su elección de compra en el precio o en el envase del producto. La mayor proporción de consumidores $(88,4 \%)$ prefirió arroz chileno.
\end{abstract}

Palabras clave: Arroz, importación, origen, Oryza sativa, segmentos de mercado.

\section{References}

Acebrón, L.B., and L.C. Dopico. 2000. The importance of intrinsic and extrinsic cues to expected and experienced quality: an empirical application to beef. Food Quality and Preference 11:229238.

Agrawald, J., and W.A. Kamakura. 1999. Country of origin: A competitive advantage? International Research in Marketing 16:225-267.

Ahmed, Z.U., J.P. Jonson, X. Yang, C.K. Teng, and 
L.C. Boon. 2004. Does country of origin matter for low-involvement products? International Marketing Review 21:102-120.

Alfnes, F. 2004. Stated preferences for imported and hormone-treated beef: application of a mixed logit model. European Review of Agricultural Economics 31:19-37.

Andrews, R., and I. Currim. 2003. Recovering and profiling the true segmentation structure in markets: an empirical investigation. International Journal of Research in Marketing 20:177-192.

Anónimo. 2004. Mapa Socioeconómico de Chile. Adimark, Investigación de Mercados y Opinión Pública. Santiago, Chile. www.adimark.cl (Accessed: April 2005).

Baker, M., and L. Ballington. 2002. Country of origin as a source of competitive advantage. Journal of Strategic Marketing 10:157-168.

Baker, G., and T. Burnham. 2002. The market for genetically modified foods: consumer characteristics and policy implications. International Food and Agribusiness Management Review 4:351360 .

Balestrini, P., and P. Gamble. 2006. Country-of-origin effects on Chinese wine consumers. British Food Journal 108:396-412.

Baltas, G., and P. Doyle. 1998. An empirical analysis of private brand demand recognizing heterogeneous preferences and choice dynamics. Journal of the Operational Research Society 49:790798.

Bernués, A., A. Olaizola, and K. Corcoran. 2003. Extrinsic attributes of red meat as indicators of quality in Europe: an application for market segmentation. Food Quality and Preference 14:265276.

Bonnet, C., and M. Simioni. 2001. Assessing consumer response to protected designation of origin labeling: a mixed multinomial logit approach. European Review of Agricultural Economics 28:433-449.

Chambers, S., A. Loob, L. Butler, K. Harvey, and W.B. Traill. 2007. Local, national and imported foods: a qualitative study. Appetite 49:208-213.

De Cicco, A., M. Loseby, and I. van der Lans. 2001. The role of eu-certification of region of origin in consumer evaluation of food products. Pages 67-69. In: L. M. Albisu (ed.). Proceedings of the $71^{\text {st }}$ EAAE seminar, the food consumer in the $21^{\text {st }}$ century, Zaragoza, Spain.

Fernández, A. 2002. Investigación y Técnicas de Mercado. Primera ed. Editorial Esic, Madrid, Es- paña. 273 pp.

Grunert, K.G. 2005. Food quality and safety: consumer perception and demand. European Review of Agricultural Economics 32:369-391.

Gürhan-Canli, Z., and D. Maheswaran. 2000. Determinants of country-of-origin evaluations. Journal of Consumer Research 27:96-108.

Hair, J., R. Anderson, R. Tatham, and W. Black. 1999. Análisis Multivariante. Otero. Quinta ed. Prentice Hall Internacional, Inc. Madrid, España. $832 \mathrm{pp}$.

Juric, B., and A. Worsley. 1998. Consumers' attitudes towards imported food products. Food Quality and Preference 9:431-441.

Kaynak, E., O. Kucukemiroglu, and A.S. Hyder. 2000. Consumers' country-of-origin (CCO) perceptions of imported products in a homogeneous less-development country. European Journal of Marketing 34:1221-1241.

Knight, J., G. Hongzhi, T. Garrets, and K. Deans. 2008. Quest for social safety in imported foods in China: Gatekeeper perceptions. Appetite 50:146157.

Kotler, P. 2002. Conceptos esenciales. Dirección de Marketing. Primera ed. Editorial Prentice-Hall. México. $351 \mathrm{pp}$.

Lantz, G., and S. Loeb. 1996. Country of origin and ethnocentrism: An analysis of Canadian and American preferences using social identity theory. Advances in Consumer Research 23:374378.

Lea, P., M. Rodbotten, and T. Naes. 1997. Analysis of variance for sensory data. First edition. John Wiley and Son. Chichester, United Kingdom. $102 \mathrm{pp}$.

ODEPA. 2008. Boletín Estadístico de Comercio Exterior Silvoagropecuario. Enero - Diciembre 2007. $\mathrm{N}^{\circ}$ 48. www.odepa.gob.cl/odepaweb/servicios-informacion/ComexTrim/Bol-Trimestral48.pf. (Consultado: julio de 2008)

Oliver, M.A., G.R. Nute, I. Font, M. Furnols, R. San Julián, M.M. Campo, C. Sañudo, V. Cañeque, L. Guerrero, I. Alvarez, M.T. Díaz, W. Branscheid, M. Wicke, and F. Montossi. 2006. Eating quality for beef, from different production system, assessed by German, Spanish and British consumers. Meat Science 74:435-442.

Orth, U., and Z. Firbasová. 2003. The role of consumer ethnocentrism in food product evaluation. Agribusiness 19:137-153.

Ozretic-Dosen, D., V. Skare, and Z. Krupka. 2007. Assessments of country of origin and brand cues 
in evaluating a Croatian, western and eastern European food product. Journal of Business Research 60:130-136.

Rojsek, I. 2001. A comparison of the purchasing and consumption behavior of Slovenian and Eastern European consumers. International Marketing Review 18:509-520.

Schnettler, B. O. Manquilef y H. Miranda. 2004. Atributos valorados en la selección de carne bovina en supermercados de Temuco, IX Región de Chile. Ciencia e Investigación Agraria 31:91100.

Schnettler, B., D. Ruiz, O. Sepúlveda, and N. Sepúlveda. 2008. Importance of the country of origin in food consumption in a developing country. Food Quality and Preference 19:372-382.

Stiving, M. 2000. Price-ending when prices signal quality. Management Science 46:1617-1629.

Tomlins, K.I., J.T. Manful, P. Larwer, and L. Hammond. 2005. Urban consumer preferences and sensory evaluation of locally produced and imported rice in West Africa. Food Quality and Preference 16:79-89.

Van der Lans, I.A., K. van Ittersum, A. De Cicco, and
M. Loseby. 2001. The role of origin in consumer evaluation of food products. European Review of Agricultural Economics 28:451-477.

Van Ittersum, K., M. Candel, and M. Meulenberg. 2003. The influence of the image of a product's region of origin on product evaluation. Journal of Business Research 56:215-226.

Verbeke, W., and R.W. Ward. 2006. Consumer interest in information cues denoting quality, traceability and origin: An application of ordered probit models to beef labels. Food Quality and Preference 17:453-467.

Verlegh, P.W.J., and J.-B.E.M. Steenkamp. 1999. A review and meta-analysis of country-of-origin research. Journal of Economic Psychology 20:521-546.

Verlegh, P.W.J., J.-B.E.M. Steenkamp, and M. Meulenberg. 2005. Country-of-origin effects in consumer processing of advertising claims. International Journal of Research in Marketing 22:127-139.

Witkowski, T. 1998. Consumer ethnocentrism in two emerging markets: Determinants and predictive validity. Advances in Consumer Research 25:258-263. 